\title{
Project-based Learning (PBL) in EFL Learning: Lessons from Indonesia
}

\author{
Ngadiso $^{1}$, Teguh Sarosa ${ }^{2}$, Muhammad Asrori 3, Nur Arifah Drajati4, Anis \\ Handayani5
}

DOI: $10.35445 /$ alishlah.v13i2.558

\section{Article Info}

Keywords:

EFL;

Learning experience;

Project-Based Learning

Kata kunci:

EFL;

Pengalaman Belajar;

Pembelajaran berbasis proyek

\begin{abstract}
Project-based learning (PBL) has gained popularity in education recently. This teaching method provides opportunities for students to learn independently by doing group works in the form of a project. It is seen as a suitable method to teach EFL to replace the traditional ways of teaching. Thus, this case study explores the students' and teachers' experience implementing PBL in the EFL class. Three EFL classes from three different high schools in Indonesia were observed to explore this issue. Six students and three teachers were interviewed to confirm the observation's result and determine their perception of learning using PBL. The findings show that the class situation improved positively after implementing PBL. Furthermore, PBL was well perceived by both students and teachers. The teaching and learning process went smoothly and well-controlled. The students and teachers show positive perceptions toward PBL in EFL classes. However, some negative points of PBL were also pointed out. Thus, educational sectors may use this study's results to improve the educational quality, specifically for EFL classes.
\end{abstract}

\begin{abstract}
Abstrak
Pembelajaran berbasis proyek (PBL) cukup popular in dunia pendidikan saat ini. Metode pembelajaran ini memberi kesempatan siswa untuk belajar secara mandiri dengan melakukan proyek secara berkelompok. Metode ini dilihat sebagai metode yang tepat untuk mengajarkan bahasa inggris untuk menggantikan metode tradisional. Oleh karena itu, penelitian studi kasus ini menjabarkan pengalaman siswa dan guru dalam menerapkan PBL dalam pembelajaran bahasa inggris. Tiga kelas dari tiga SMA di Indonesia diteliti untuk menjabarkan hal ini. Lebih jauh lagi, enam siswa dan tiga guru bahasa inggris dari kelas-kelas tersebut diwawancarai untuk mengkonfirmasi hasil observasi dan mengetahui persepsi mereka mengenai penerapan PBL di kelas bahasa inggris. Hasil penelitian ini menunjukkan bahwa situasi kelas meningkat secara positif setelah penerapan PBL. Lebih jauh lagi, PBL diterima dengan baik oleh siswa dan guru. Proses belajar mengajar berjalan lancar dan terkontrol. Para siswa dan guru menunjukan respon positif terhadap PBL. Namun, beberapa poin negatif PBL juga ditunjukkan. Oleh karena itu, sektor pendidikan bisa menggunakan hasil penelitian ini untuk meningkatkan kualitas pendidikan, terutama dalam kelas bahasa inggris.
\end{abstract}

\footnotetext{
${ }^{1}$ Universitas Sebelas Maret, Surakarta, Indonesia Email: ngadisodok@yahoo.com

2 Universitas Sebelas Maret, Surakarta, Indonesia Email: teguhsrs@yahoo.com

3 Universitas Sebelas Maret, Surakarta, Indonesia

Email: asrori_asli@yahoo.co.id

4 Universitas Sebelas Maret, Surakarta, Indonesia

Email: nurarifah_drajati@staff.uns.ac.id

5 Universitas Sebelas Maret, Surakarta, Indonesia

Email: anishandayani@student.uns.ac.id
} 


\section{INTRODUCTION}

Project-based learning (PBL) has been increasingly popular in mainstream education (Greenier \& Greenier, 2018). As a teaching method, project-based learning allows the students "to drive their learning through inquiry, as work collaboratively to research and create projects that reflect their knowledge" (Bell, 2010, pp. 39). In this teaching method, students are often given a project to practice their teamwork skills by collaborating with their peers (Helle et al., 2006). The teacher here is a facilitator guiding the students doing their projects (King \& Smith, 2020). In a PBL classroom, the students may work in the group to plan, work, and present. At the end of the term, the students were commonly asked to present their projects to communicate their ideas to their peers (King \& Smith, 2020). PBL creates a situation where the learning process will be more exciting and real-world focus than having the teacher's explanation, such as in traditional teaching methods (Lee et al., 2014).

PBL offers many opportunities to promote language use and acquisition in real-life contexts because the basic premise of PBL is that learning begins with a problem presented in the same context as it will be encountered in real life (Kumaravadivelu, 2001). It means that what they learn is that the class can be directly implemented to solve real-life problems. The students will be more ready when facing real-world problems since they learned and practiced in their class. It gives the students more advantages than learning something that may not be encountered in real life (Poonpon, 2017).

PBL is done in some steps. Stoller (2002) shows that the teaching steps of PBL are as follows: (1) Students and teacher agree on a theme for the project; (2) Students and teacher determine the outcome of the project; (3) Students and teacher structure the project; (4) Teacher prepares students for the demands of information gathering; (5) Students gather information; (6) Teacher prepares students to compile and analyze data; (7) Students compile and analyze information; (8) Teacher prepares students for the language demands of the last activity; (9) Students present the final product; and (10) Students evaluate the project. However, the implementation in the language is rarely explored. Here we can see that the students are actively involved in the teaching-learning process from determining the outcomes until evaluating the results. The students are the active participants in the learning process, while the teacher acts as their guidance or facilitator rather than the primary learning source (King \& Smith, 2020).

EFL has been taught traditionally in Indonesia, in which this study took place, for years. Greenier \& Greenier (2018) emphasize that most teaching and learning processes, including EFL, use lecturing as their teaching method. A preliminary study reveals that this teaching method often makes the students bored since they only listen to the teacher's explanation. In this learning setting, the teacher acts as the primary source that makes it more teacher-centered. Undoubtedly, it is not in line with the current curriculum's educational purpose, the 2013 curriculum, which gives students more opportunities to learn independently. To allow students to have such opportunities and make the teacher acts as a guidance or facilitator instead of a controller, this PBL has been used as an alternative teaching method. Furthermore, Astawa et al. (2017) found that PBL improved students' enthusiasm, confidence, self-directed learning, and collaborative learning.

Considering its importance in education, PBL has drawn the attention of researchers. Azman \& Shin (2012) examined the undergraduate students' perception of implementing PBL in learning English as a second language and found that the student had a positive perception toward PBL. In 2015, Kavlu showed that reading and acquiring the required vocabulary were more enjoyable when using PBL. The students were more motivated and interested in learning, as similarly found by Chu et al. (2017). Meanwhile, Wang (2016) applied PBL to enhance students' motivation using a survey and found that the students were more motivated in learning using PBL as a teaching method. Furthermore, Greenier \& Greenier (2018) conducted a study on implementing the 10Cs of the PBL TESOL curriculum and found that both the students and teachers have complementary views on this 
new curriculum since it is more exciting and engaging than the teacher-centered approach. Furthermore, the students confess that they can develop their communicative skills and creativity while learning English using this PBL.

Considering the prior studies, it seems that the teachers' perception of implementing PBL was least explored. Thus, our study aims to find: (1) the class situation before and after implementing PBL as a teaching method and (2) the students' and the teachers' perception of implementing PBL in learning English as a foreign language.

\section{METHOD}

We conducted this study in 3 English classes in three Indonesian high schools. Furthermore, the schools in which the research took place have different characteristics. Table 1 presents the school demography.

Table 1. The school demography

\begin{tabular}{|c|c|c|c|}
\hline Aspect & School A & School B & School C \\
\hline Type of school & State school & State school & Private school \\
\hline $\begin{array}{l}\text { Students' English } \\
\text { proficiency }\end{array}$ & High & Average & Low \\
\hline $\begin{array}{c}\text { Teacher's way of } \\
\text { teaching }\end{array}$ & $\begin{array}{l}\text { Textbook-based, } \\
\text { lecturing }\end{array}$ & Lecturing & Task-based \\
\hline
\end{tabular}

Before observing the PBL's implementation, we observed the class situation where the teaching and learning process was using the lecturing method. It was conducted two meetings before implementing PBL. The data were then used to compare the class situation before and after implementing PBL.

To know the implementation of PBL, then, we observed the teaching-learning process for two meetings for each class. A total of three English teachers and 97 students from three different classes and schools participated in this study. We summarized the class activities in learning "how to make caption" using PBL in table 2.

Table 2. The class activity

\begin{tabular}{cl}
\hline Meeting & Activity \\
\hline 1 & The students watched a video of making a caption provided by the teacher. \\
& They asked questions about the content of the video. \\
& They observed and identified the caption provided by the teacher. \\
They, along with the teacher, discussed how to make a caption. \\
They, in groups of five, identified some captions to find out their differences. \\
They, along with the teacher, discussed the differences among those captions. \\
They, along with the teacher, discussed the teenage social problems in their daily life. \\
They decided on one social problem and planned to make a caption based on the problem. \\
They reported on the project progress via an online video sent to their teacher. (This step was \\
done outside the classroom.) \\
The student group presented their caption in front of the class. \\
The other groups and the teacher gave feedback on their caption. \\
The students, along with the teacher, did a reflection on their groups' presentations.
\end{tabular}

The observation was conducted in 2 meetings for each class. Four aspects of the teachinglearning process were observed: teaching, learning process, students' participation, and students' achievement. The researchers conducted this observation, recording the teaching-learning process, taking notes, and filling the prepared form. Once the observation was done, we wrote the results to avoid data loss. Then, once we finished observing the classes in 6 meetings ( 2 meetings for each class), we analyzed the data using an interactive model proposed by Miles et al. (2014), including data collection, data condensation, data display, and concluding. We analyzed the data separately to 
avoid research bias. The data were analyzed under four themes: a way of teaching, the learning process, students' participation, and students' achievement. Then, we discussed and concluded.

To confirm its results and determine the participants' perception of learning English using PBL, semi-structured interviews were conducted with three teachers and six students from the three classes. Before the interviews began, they were informed about the study's aims, how it was done, and their benefits from participating. The interviews were taken place in a quiet room within the schools or nearby café according to the participants' preference. After the data was collected and transcribed, they were analyzed based on two main themes, affordances and disadvantages of using PBL in EFL class, viewed from the teachers' and students' perceptions. Then, the results were confirmed with the participants to maintain their credibility. Last, the conclusion was drawn from the results.

\section{FINDINGS AND DISCUSSION}

\section{The Class Situation After Implementing Project-Based Learning}

Here we collected the data from the class observation in a semester (six months). There is a difference in the class situation before and after the implementation of PBL. Table 3-5 summarizes the class situation in the three schools before and after implementing PBL.

Table 3. The class situation before and after the implementation of PBL in school A

\begin{tabular}{|c|c|c|}
\hline Aspect & Before implementing PBL & After implementing PBL \\
\hline \multirow[t]{2}{*}{ Way of teaching } & $\begin{array}{l}\text { The teacher explained the materials } \\
\text { provided in the textbook. }\end{array}$ & $\begin{array}{l}\text { The students did the project under the } \\
\text { teacher's guidance (student-centered). }\end{array}$ \\
\hline & $\begin{array}{l}\text { Teacher-centered. } \\
\text { The teacher often asked the students to } \\
\text { answer the questions provided in the } \\
\text { worksheet. }\end{array}$ & $\begin{array}{l}\text { The students were involved in } \\
\text { determining the project's steps, such as } \\
\text { dividing the work and determining the } \\
\text { schedule. }\end{array}$ \\
\hline Learning process & $\begin{array}{l}\text { The class was done following the order of } \\
\text { the materials in the textbook. }\end{array}$ & $\begin{array}{l}\text { The class was done following the order of } \\
\text { PBL steps. }\end{array}$ \\
\hline $\begin{array}{l}\text { Students' } \\
\text { participation }\end{array}$ & $\begin{array}{l}\text { The students are passively involved in the } \\
\text { learning process. }\end{array}$ & $\begin{array}{l}\text { The students are actively involved in } \\
\text { creating the materials and learning them } \\
\text { independently. }\end{array}$ \\
\hline $\begin{array}{l}\text { Students' } \\
\text { achievement }\end{array}$ & $\begin{array}{l}\text { The students' reasoning, teamwork, } \\
\text { creativity, and communication skills were } \\
\text { not developed yet. }\end{array}$ & $\begin{array}{l}\text { The students' reasoning, teamwork, } \\
\text { creativity, and communication skills were } \\
\text { improved, such as the students' reasoning } \\
\text { to make a useful product, creativity in } \\
\text { creating a product, collaboration in } \\
\text { teams, and communication in } \\
\text { communicating ideas and project results. }\end{array}$ \\
\hline
\end{tabular}

Table 4. The class situation before and after the implantation of PBL in school B

\begin{tabular}{lll}
\hline Aspect & Before implementing PBL & After implementing PBL \\
\hline Ways of teaching & $\begin{array}{l}\text { Lecturing. } \\
\text { Teacher-centered. }\end{array}$ & $\begin{array}{l}\text { The students worked in teams and were } \\
\text { active in the learning process (student- } \\
\text { centered). }\end{array}$ \\
& $\begin{array}{l}\text { The teacher often asked the students to } \\
\text { answer the questions provided in the }\end{array}$
\end{tabular}
worksheet.

There was no two ways of communication. The learning system could be recognized easily. 
The teacher used the learning tools ineffectively.

Learning process The students answered questions from the teacher.

The students listened to the teacher's explanation, passively.

Students' participation

The students are passively involved in the learning process.
The class was done following the order of PBL steps.

The students learn independently by doing group projects.

The students interact with their peers in doing the projects.

The students are actively involved in creating the materials and learning them independently.

The students are actively involved in doing the projects in their groups.

The students' reasoning, teamwork skills, and creativity were improved.
Students' The students only mastered a particular achievement

$$
\text { skill. }
$$

The students were not creative and innovative.

Table 5. The class situation before and after the implantation of PBL in school C

\begin{tabular}{|c|c|c|}
\hline \multirow{2}{*}{$\begin{array}{l}\text { Aspect } \\
\text { Ways of teaching }\end{array}$} & Before implementing PBL & After implementing PBL \\
\hline & $\begin{array}{l}\text { Lecturing. } \\
\text { Teacher-centered. } \\
\text { The teacher often asked the students to } \\
\text { answer the questions provided in the } \\
\text { worksheet. }\end{array}$ & $\begin{array}{l}\text { The students worked in teams and were } \\
\text { active in the learning process (student- } \\
\text { centered). }\end{array}$ \\
\hline \multirow[t]{3}{*}{ Learning process } & $\begin{array}{l}\text { The students learned the materials from } \\
\text { the teacher's slides. }\end{array}$ & $\begin{array}{l}\text { The students searched for the materials. } \\
\text { The students discussed it in teams. }\end{array}$ \\
\hline & $\begin{array}{l}\text { The students discussed the content with } \\
\text { their friends. }\end{array}$ & $\begin{array}{l}\text { The students summarized and wrote the } \\
\text { results. }\end{array}$ \\
\hline & $\begin{array}{l}\text { The students presented their discussion } \\
\text { results. }\end{array}$ & The students presented the results. \\
\hline $\begin{array}{l}\text { Students' } \\
\text { participation }\end{array}$ & $\begin{array}{l}\text { The students are passively involved in the } \\
\text { learning process. }\end{array}$ & $\begin{array}{l}\text { The students are actively involved in } \\
\text { doing the project and presenting the } \\
\text { results. }\end{array}$ \\
\hline $\begin{array}{l}\text { Students' } \\
\text { achievement }\end{array}$ & Not all linguistic skills were developed. & $\begin{array}{l}\text { The students' reasoning, teamwork skills, } \\
\text { and creativity were improved. }\end{array}$ \\
\hline
\end{tabular}

Ways of Teaching

Before implementing PBL, the teachers mainly used traditional teaching methods in teaching English. They explained the textbooks' materials (textbook-based), and the students were asked to answer the provided questions. The students were rarely given opportunities to interact with other students. They only learned from their teachers' explanations. Furthermore, there was rarely communication between the teacher and the students. Besides, the teachers often asked the students to answer questions provided in the textbook. Then, the upcoming days would be the teachers' confirmation of the correct answers, repeatedly.

After implementing PBL, the teachers' ways of teaching changed positively. They were no longer using textbooks as the primary source. They instead used more authentic materials to give examples for the students' projects. Furthermore, rather than explaining the materials, they guided the students in doing the projects. They rarely asked the students to answer the questions in the textbooks. They observed and guided the students, so the teaching-learning process is more student- 
centered and motivating. This finding supports Astawa et al.'s (2017) finding that PBL enhances students' self-directed skill and motivation in learning, especially EFL.

\section{The Learning Process}

Before implementing PBL, the learning process mainly consisted of the teachers' explanations. The students only listened to the teacher's explanation. The students were relatively silent. Many students often yawned, which could be inferred that they were sleepy and bored. Furthermore, the class followed the materials provided in the textbooks. The class was rather textbook-based. The students were mainly asked to answer the questions, and the teacher would provide the correct answers directly in the following days without discussing with the students.

After implementing PBL, the learning process significantly changed. Before, the students only sat down on their chairs, but after implementing PBL, they discussed and interacted with other students. They moved from their destined chairs to discuss in groups. They searched for the materials, discussed the projects, and prepared the presentation to communicate the ideas. The class was more active and noisy when the students were having discussions than before implementing PBL. Furthermore, the students could be less bored since they talked, laughed, and discussed with their friends. Azman \& Shin (2012) found that students enjoy learning EFL using PBL since they can discuss, prepare a presentation, and so on. It brings the students closer to other ones.

\section{Students' Participation}

Before implementing PBL, the students were passively involved in the teaching and learning process. The materials were decided by the teachers, taken from the textbooks. The students only listened to the teacher's explanation. There was rarely any interaction between the students and the teachers. There were only a few students asking questions to the teacher. Furthermore, the rest of the students were only silent, listening to the teacher's explanation.

After implementing PBL, the students' participation increased. This finding is in line with Mali's (2016) findings that PBL increases students' participation in learning. The students were directly involved in the teaching and learning process. They were participated in choosing the materials. Although the project topic was the same for all groups, they could decide on sub-topics based on their interests. The teachers did not have complete control over what they want to do in the projects.

Furthermore, the teachers acted as the facilitators or guidance, so they stood in front of the class and walked around supervising the groups doing the activities. It surprisingly encouraged the students to ask questions actively. Effective communication between the teacher and students could be achieved. There was a discussion between the groups and the teacher in making the projects successful.

\section{Students'Achievement}

Before implementing PBL, the students' achievement was less satisfying. Their reasoning and creativity were relatively low. It may happen since the previous teaching method did not stimulate and develop these skills. Furthermore, the students worked collaboratively. They did not have the chance to work in groups or interact with other students, so their social and teamwork skills were relatively low. They were not used to work in a group, which led to their teamwork skills decrease.

After implementing PBL, the students' achievement, specifically in reasoning and creativity, improved. It was the result of having those skills practiced in implementing PBL. There the students created a project, discussed with the groups, and communicated the ideas or projects. They practiced their creativity in creating and designing the projects. Furthermore, the students practiced their reasoning in communicating the projects. Each group presented their projects, and other groups responded by giving some questions.

These results show that PBL was well implemented in EFL classes. It was proved that PBL improved class situations and developed students' skills, which could not be improved when learning using the traditional approach. These results support Fragoulis's (2009) and Greenier \& Greenier's 
(2018) studies that PBL promotes students' knowledge growth, problem-solving skills, risk-taking, collaboration, and empathy. It means that PBL could be implemented well in the EFL class, which was beneficial for the students.

\section{The students' and teachers' perception of learning English using project-based learning}

Here we collected the data from the students' and teachers' interviews on how they view the implementation of PBL in the EFL class. They tell their experiences as well as their perception of teaching and learning English using PBL.

\section{Students' perception}

The students were more motivated to learn English using this method compared to other methods. They experienced that PBL created a situation in which they could interact with other students while learning. It results in improved solidarity in the class. It created a lively and active class that was suitable for the students to learn.

\section{Extract 1:}

"I like doing this project. It makes us (the students) ... closer to each other. We read, discuss, and prepare the project together." (Student B)

This finding is in line with Gomez-Pablos et al.'s (2017) finding that PBL increased students' learning motivation and active class participation. The students here confessed that they are more motivated to learn using PBL rather than other learning methods. However, the extended project may decrease students' motivation (Fragoulis, 2009). The teachers need to pay attention to the project's length to avoid students' boredom in doing such a long project.

Another good point of PBL, they said, is that PBL gives a real-life learning experience. They created a project about a real object (e.g., A caption for a picture) that they felt that they learned something real. Then, the last good point is that PBL stimulates the students to create new project ideas. It is a good point since the students may use this ability to learn other courses in the future.

\section{Extract 2:}

"We may have to do something similar (project) in our life. So, yeah, I like it more than the previous one (the teaching method)." (Student E)

Asides from the good points, the students also point out some negative points of PBL. The first one is that they struggled in managing the time to do the project. The members have their activities, so it is quite challenging to decide the time and finish the project in the expected period.

\section{Extract 3:}

"We (students) have different things to do, so, emmm, sometimes we find it difficult to match our schedule to do our task (project)." (Student C)

Another point is that some members were not cooperative in doing the project. They were somewhat ignorant of their job in the group. They just sat and did nothing while the others were doing the projects. They confessed that it decreased the group's motivation to do the project.

\section{Extract 4:}

"Yes, someone just come and sits, and do nothing while the others are doing the project. We (the group members) become unmotivated because of this such person." (Student B)

\section{Teacher's perception}

The teachers mentioned that PBL created students' active participation in class. They experienced that the students appeared to be happier when learning using PBL than using other methods. They could make the class more interesting. They also confessed that the students' 
achievement improved after implementing PBL. The students' reasoning, creativity, and teamwork improved.

\section{Extract 5:}

"The students become more active in class. Also, they seem to be improved in their reasoning skills.” (Teacher $A$ )

The students could practice and improve language skills such as communicative skills, teamwork, and creativity by learning English using PBL. The same results were found by Poonpon (2017), in which the students were benefitted by using PBL in learning English. In the study, the students enjoyed learning using PBL than using traditional methods. However, the results also revealed that the teacher did not give the students enough preparation to have a presentation and enough time to prepare the presentation.

Furthermore, the teachers believed that using PBL could give them more experience exploring different teaching methods and make them more creative in creating teaching and learning materials. They said that previously they just did the same thing every time. However, in using PBL, they could practice more often in creating exciting materials. This finding supports Mali's (2016) finding that PBL gives teachers ideas to be more innovative in creating teaching materials.

\section{Extract 6:}

"Yes, of course. I feel like I ... become a more creative teacher. I mean, I create more creative and interesting materials for my students." (Teacher A)

However, still, they had some difficulties in implementing this teaching method, as found by Gomez-Pablos et al. (2017). The teachers here confessed that PBL gives an unclear contribution to each group member. They struggled in grading the students' participation fairly. They were rather anxious in grading the students' works since they did not know how each member contributed to the group's project. Furthermore, they spotted that some students were not excited about using PBL, specifically introverted and unconfident ones. They found it challenging to motivate such students to interact with their peers and participate actively in the group project.

\section{Extract 7:}

"The most difficult thing to do in PBL is grading. I do not think I give a fair score to my students. I cannot supervise them all the time, right?" (Teacher C)

This kind of problem also appeared in Fragoulis's (2009)'s study. He found that teachers often found it challenging to grade their students fairly since they did not directly supervise their work. They have a tendency only to grade the student based on the final project, which does not ensure fairness in grading the students. Thus, it seems that PBL needs to have a fixed grading system to ease the teachers in grading the students.

\section{CONCLUSION}

PBL is believed to make the teaching-learning process more interesting for the students. This study shows an improvement in the ways of teaching, learning process, students' participation, and students' achievement. The class that was then boring now is more interesting, allowing students to participate actively in the learning process. The students were no longer listeners, but instead, they were the doers who control the learning materials and steps. Furthermore, after implementing PBL, the students' reasoning and creativity may improve since they practice these skills to create an exciting project and communicate it.

Furthermore, both the students and teachers have a positive perception of implementing PBL in EFL classes. They enjoyed learning using PBL since they could develop skills that could not be developed when using previous teaching methods. They were benefitted from learning EFL using PBL.

This study has two weaknesses. First, it only used small-scale data sources. Thus, further studies may use more extensive and more heterogeneous data sources to get more generalized results. Second, this study only used qualitative data, so another study combining qualitative and 
quantitative data may be worthwhile to conduct. It may give more valid and sophisticated results. At last, this study found that PBL could be implemented well in a language class, specifically EFL. However, it has several weaknesses that need to be considered in implementing it in the language classroom in the future. All educational sectors, specifically English language teachers, should improve the quality of English classes using PBL by considering its affordances and disadvantages.

\section{REFERENCES}

Astawa, N. L. P. N. S. P., Artini, L. P., \& Nitiasih, P. K. (2017). Project-based learning activities and efl students' productive skills in english. Journal of Language Teaching and Research, 8(6), 1147-1155. https://doi.org/10.17507/jltr.0806.16

Azman, N., \& Shin, L. K. (2012). Problem-based learning in English for a second language classroom: Students' perspectives. International Journal of Learning, 18(6), 109-126. https://doi.org/10.18848/1447-9494/cgp/v18io6/47648

Bell, S. (2010). for the Future Project-Based Learning for the 21st Century : Skills for. 8655. https://doi.org/10.1080/o0098650903505415

Chu, S. K. W., Zhang, Y., Chen, K., Chan, C. K., Lee, C. W. Y., Zou, E., \& Lau, W. (2017). The effectiveness of wikis for project-based learning in different disciplines in higher education. The Internet and Higher Education, 33, 49-60. https://doi.org/10.1016/j.iheduc.2017.01.005

Fragoulis, I. (2009). Project-Based Learning in the Teaching of English as A Foreign Language in Greek Primary Schools : From Theory to Practice. English Language Teaching, 2(3), 113-119.

Gomez-Pablos, V. B., Pozo, M. M. del, \& Munoz-Repiso, A. G.-V. (2017). Project-based learning ( PBL ) through the incorporation of digital technologies : An evaluation based on the experience of serving teachers nica Basilotta $\mathrm{G}$ o Ver o rcel Mu n. Computers in Human Behavior, 68, 501-512. https://doi.org/10.1016/j.chb.2016.11.056

Greenier, V. T., \& Greenier, V. T. (2018). The 10Cs of project-based learning TESOL curriculum The $10 \mathrm{Cs}$ of project-based learning TESOL curriculum. Innovation in Language Learning and Teaching, $o(0), 1-10$. https://doi.org/10.1080/17501229.2018.1473405

Helle, L., Tynjälä, P., \& Olkinuora, E. (2006). Project-based learning in post-secondary education Theory, practice and rubber sling shots. Higher Education, 51(2), 287-314. https://doi.org/10.1007/s10734-004-6386-5

Kavlu, A. (2015). The Effect of Project-Based Learning on Undergraduate EFL Students' Reading Comprehension Ability. Journal of Education in Black Sea Region, 1(1). https://doi.org/10.31578/jebs.v1i1.8

King, B., \& Smith, C. (2020). The Clearing House : A Journal of Educational Strategies , Using Project-Based Learning to Develop Teachers for Leadership Using Project-Based Learning to Develop Teachers for Leadership. The Clearing House: A Journal of Educational Strategies, Issues and Ideas, $o(0), 1-7 . \mathrm{https}: / /$ doi.org/10.1080/00098655.2020.1735289

Kumaravadivelu, B. (2001). Toward a Postmethod Pedagogy. TESOL Quarterly, 35(4), 537. https://doi.org/10.2307/3588427

Lee, J. S., Blackwell, S., Drake, J., \& Moran, K. A. (2014). Taking a Leap of Faith: Redefining Teaching and Learning in Higher Education Through Project-Based Learning. Interdisciplinary Journal of Problem-Based Learning, 8(2), 3-13. https://doi.org/10.7771/1541-5015.1426

Mali, Y. C. G. (2016). Project-based Learning In Indonesian EFL Classrooms: From Theory to Practice. Indonesian Journal of English Education, 3(1), 89-105. https://doi.org/10.15408/ijee.v3i1.2651

Miles, M. B., Huberman, M., \& Saldana, J. (2014). Qualitative Data Analysis: A Methods Sourcebook (3rd Editio). Sage Publications, Inc.

Poonpon, K. (2017). Enhancing English Skills through Project-Based Learning. The English Teacher, $X L, 1-10$.

Stoller, F. L. (2002). Project Work: A Means to Promote Language and Content. In Methodology in Language Teaching (pp. 107-120). Cambridge University Press. https://doi.org/10.1017/cbo9780511667190.016

Wang, B.-T. (2016). Applying Pbl and Zuvio To Enhance English Learning Motivation. International Journal of Cyber Society and Education, 9(1), 1-16. https://doi.org/10.7903/ijcse.1433 